\title{
Modelling transportation of desert dust to the South Caucasus using WRF Chem model
}

\author{
Teimuraz Davitashvili* \\ Tbilisi State University, I. Vekua Institute of Applied Mathematics, 0186, 2 University Str., Tbilisi, Georgia
}

\begin{abstract}
The problem of the ongoing climate change resulting from natural and growing anthropogenic factors acquires a particular importance for the territory of the Caucasus. Dust aerosol represent one of the main pollutants on the territory of Georgia and impact on regional climate. In this study, the WRF Chemistry model with dust module is used to study transportation of dust to the territory of the South Caucasus from the Sahara and Sahel in Africa, Arabian and ar-Rub' al-Khali deserts located in the Middle East, Kyzylkum, Karakum in the Central Asia. The results of calculations have shown the WRF model was able to simulate dust aerosols transportation to the Caucasus reliably in conditions of the complex topography and that dust aerosol is an important factor in the climate system of the South Caucasus.
\end{abstract}

\section{Introduction}

According to Georgian National Environment Agency (GNEA) dust aerosols represent one of the main pollutants on the territory of Georgia. Dust aerosol originate from deflation of erodible sediments, volcanic eruptions, anthropogenic pollution and biomass burning. The desert dust and smoke originated from biomass burning and anthropogenic pollution, are the main sources of atmospheric aerosol [1]. Aeolian Dust Aerosol (ADA) scatter and absorb shortwave and longwave radiation, impacting radiation budget and energy balance of the atmosphere and the Earth's surface, reducing visibility and affecting the formation of precipitation [2]. Besides, dust particles can rearrange the molecular and ionic structures of the polluted atmosphere due to chemical reactions [3]. So due to chemical reactions and physical actions ADA impact on dust chemistry, on atmospheric composition, and in case of settled onto or into clouds condensate cloud nucleus, alter clouds albedo, particles size, changing the optical propertied of clouds and thereby put obstacles in the way of clouds and precipitations normal formation (indirect effect) and impact on climate [3,4]. A number of studies have been devoted to the question of origination and chemistry of long-travelled desert dust (LTD) deposited in the European Alps, Central Asia, the Himalayas and Tibetan Plateau $[3,4]$. LTD deposited in the Caucasus' territory has been mainly studied for the Mt. Elbrus [5-8] and only once for the Mt. Kazbeg on the territory of Georgia [9]. A chronology of dust deposition events on the Mt. Elbrus $(5150 \mathrm{~m}$ a.s.l.) had been documented by the ice cores extracted on the Western Plateau of the Mt. Elbrus in 2009, 2012 and 2013 years and it had been found that the desert dust is deposited on the Caucasus glaciers 3-7 times in a year and it comes mainly from deserts of the Middle East and more rarely from the northern Sahara [7]. A combination of isotopic analysis of two sets of samples extracted and collected on the Western Plateau on Mt. Elbrus had shown 17 dust aerosols deposition events at elevation of $5115 \mathrm{~m}$ a.s.l. While 13 events originated in the Middle East (in the Syrian Desert and northern Mesopotamia), only four events originated in the Sahara (in north-eastern Libya and eastern Algeria) [5]. It should be noted that 14 of them has occurred in March-June, two in October and only one in February [5]. Using dust product from the SEVIRI sensor installed on the Meteosat Second Generation satellite (red-greenblue composite imagery), MODIS (atmospheric optical depth fields), HYSPLIT model and meteorological data, enabled to identify the dust aerosol deposited on 5 May 2009 on Mt. Elbrus originated in the foothills of the Djebel Akhdar in eastern Libya [6]. To study LTD depositions on Mt. Elbrus between 2009 and 2012 based on the shallow ice cores obtained at about $5000 \mathrm{~m}$ a.s.l. using HiGAM has been preplanned as a next step in this research [6]. Investigations performed by scanning electron microscopy and X-ray diffraction analysis of the first ever extracted ice core $(18 \mathrm{~m})$ of the Mt. Kazbek plateau glacier (at $\sim 500 \mathrm{~m}$ a.s.1.) has shown that dust of local origin was composed mainly by products of weathering of magmatic rocks, while clay minerals were a characteristic of dust carried over large distances, from the deserts of the Middle East and Sahara [9].

In this study, transportation of desert dust from the Sahara, Arabian and ar-Rub' al-Khali deserts in the Middle East, Kyzylkum, Karakum and the Aral Sea's the great salty basin in Central Asia, its deposition over the South Caucasus has been investigated using WRF Chem model version 3.6.1.

\footnotetext{
* Corresponding author: teimuraz.davitashvili@tsu.ge
} 


\section{Data and methods}

\subsection{Meteorological conditions}

The South Caucasus lies between the Black and the Caspian Seas and to the south of the Main Caucasus Ridge and to the north of the Lesser Caucasus Mountains. In Georgia, these two mountain systems are linked only by the Likhy Mountains, which divide the country into western and eastern sectors. There is, therefore, a natural channel for the westerly or easterly airflow which account for $67 \%$ of all observations in the territory of Georgia [10]. The Main Caucasus Ridge prevents advection from the north $(1.5 \%$ of all observations only) [11]. The southerly flow, associated mostly with weather fronts moving from warm sectors of depressions moving from the south, accounts for $21 \%$ [10-12]. Transportation of dust to the South Caucasus in general and Georgia in particular is associated with the low- and mid-tropospheric flows from the Mediterranean and Black Seas in the west, from the Caspian - Central Asia regions in the east and warm advection from the Middle East in the south [10]. The interactions between atmospheric dust, weather patterns and climate in the Caucasus region and Georgia in particular were studied in $[5-9,13]$. At present, computer simulations are actively used to study these interactions over the territory of Georgia [14].

\subsection{Description of the modelled domain}

The mesoscale, fully compressible, Eulerian nonhydrostatic WRF Chem model with several options for physical and chemical processes parameterization is widely used to investigate air quality and dust load. We have used the WRF Chem v. 3.6.1 with its research dust module for simulation of the outbreak and transport processes of dust aerosols and its impact on the Georgian air quality with two nested domain. The Caucasus (Georgia) and surrounding eastern Sahara, Middle East and western Asia deserts are the regions of interest modeled in this work. Thereto a mother domain consisting of $100 \times 124$ cells with a $37.2 \mathrm{~km}$ resolution and a nested domain consisting of $81 \times 48$ cells with a $12.4 \mathrm{~km}$ resolution (centered at $41^{\circ} 72^{\prime} \mathrm{N}, 44^{\circ} 78^{\prime} \mathrm{E}$ ) has been used in order to capture dust storms above the arid regions of North Africa, Middle East and West Asia arid regions. The model's vertical structure for both domains includes 48 layers covering the whole troposphere. WRF Chemistry and dust modules use the identical parameters and physical options with feedbacks between the chemical and physical interactions.

\subsection{Model validation}

To validate the model, comparisons between the WRF Chem v.3.6.1 model outputs and observations have been performed with different types of observations from satellites and ground based measurements and data of the Georgian Environmental Agency (Moderate Resolution Imaging Spectroradiometer (MODIS), Cloud Aerosol
Lidar and Infrared Pathfinder Satellite Observation (CALIPSO), Climate Research Unit (CRU)). The used data from MODIS were composite Red-Green-Blue (RGB) images of surface with a resolution of $500 \mathrm{~m}$ and Aerosol Optical Depth (AOD) - 0.55-micron data, obtained from the MOD04 Level Two Aerosol Product. These data have been used for assessing the calculated dust clouds and for detecting large sources of dust emissions and dust clouds. For evaluation of the model model ability to accurately reproduce the distribution of dust in the vertical direction the Total Attenuated Backscatter (TAB) TAB data were used which were obtained from CALIPSO at a $532 \mathrm{~nm}$ wavelength for the selected episode dates.

\section{Results and Discussion}

Between December 2017 and September 2018, nine dust transportation events were observed in the Caucasus. Two have been modelled and are discussed in this paper.

\subsection{Dust storm in the Sahara on 23 March 2018}

A strong dust storm developed in the eastern Sahara on 23 March 2018. The dust storm moved from northeastern Libya to Crete and the Southeastern Aegean and Rhodes Island to Turkey and the Black Sea reaching southern Russian and Georgia. This belt of dust gradually stretched eastwards during the day and then moved towards the Southern Russian and Georgian territories. On the 23 March 2018, snow and rain of redbrown colour were registered in the town of Sochi on the Russian Black Sea coast and in Georgian capital Tbilisi.

The results of numerical calculations (Fig. 1 (A)) show that the strong wind transported the dust-loaded air masses over the Black Sea to the territory of western Georgia at 20:00 on 23 March 2018. At the same time, advection from the east was observed over eastern Georgia. Simultaneous advection from west and east to

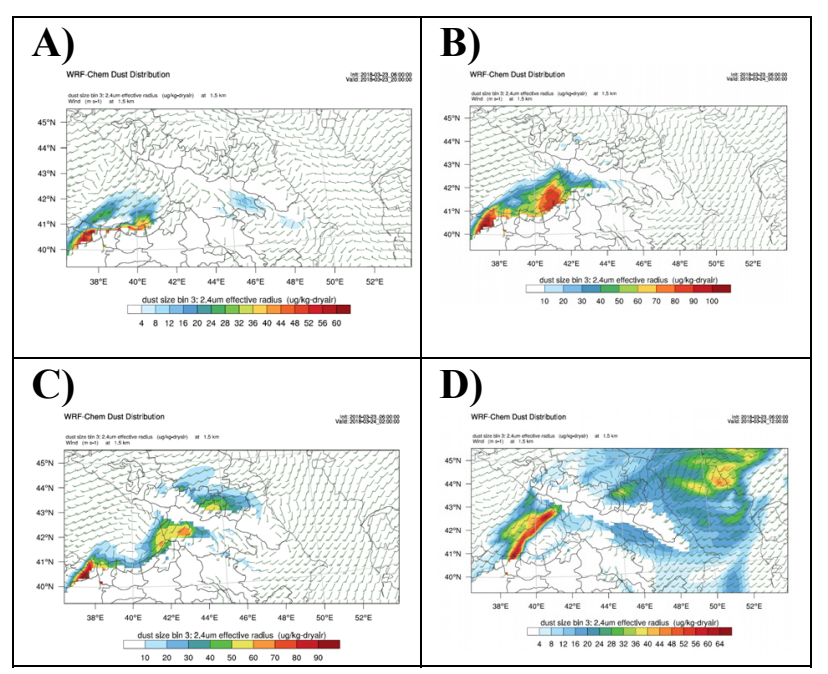

Figure 1. The results of numerical calculations executed on the fine mesh grids depicted dust plume migration from the Eastern Sahara Desert towards the territory of Georgia A) at 20:00 on 23 March; B) at 00:00 24 March 2018; C) at 02:00 on 24 March; D) at 12:00 on 24 March. 
the territory of Georgia (accounting for $1.1 \%$ of all observations [11]) was registered. But further calculations has shown that western atmosphere processes was rather strong and it brought dust particles even on the eastern territory of Georgia at 00:00 24 March 2018 (see Fig. 1 (B)). Figure 1 (C) shows that at 02:00 on 24 March air currents with dust particles have overcome the Main Caucasus Ridge and dust cloud moved north over the Main Caucasus Ridge to southern Russia. Figure 1 (D) shows that another dust cloud reached the territory of Georgia at 12 noon travelling over the Black Sea and from the Middle East. Further the dust cloud leaves the territory of Georgia at 02:00 on 25 March.

\subsection{Dust storm in Turkmenistan on 25-26 July 2018}

An unusually strong dust storm was registered in the capital city of Azerbaijan, Baku, on 26 July 2018, bringing yellow haze and reducing visibility. The Ministry of Ecology and Natural Resources of Azerbaijan has officially declared in the press that a moderate north-west wind brought dust aerosol from neighboring Turkmenistan across the Caspian Sea and the dust storm had fully covered the Absheron peninsula and changed humidity and air temperatures. On 27 July 2018 high concentrations of dust were registered in Tbilisi and its surroundings and the National Environment Agency of Georgia announced that the dust cloud was coming from Turkmenistan via Azerbaijan.

The results of calculations performed by WRF Chem model on the coarse meshes grid (mother domain), have shown that there were observed two large dust clouds over the Karakum desert and adjoining territories at a height of $800 \mathrm{~m}$ above sea level at 06:00 on 26 July 2018. Also two smaller dust clouds were observed over Syria and Iraq (Fig. 2 (A)). Figure 2 (B) shows that a larger dust cloud appeared over the Arabian Peninsula which moved towards the Indian Ocean at 08:00 on 26 July 2018. Simultaneously the Karakum dust cloud is moving west, towards the Caspian Sea. Figure 2 (C) shows that the Karakum dust cloud reached the territory of Azerbaijan at 16:00 on 26 July 2018 and intended to move to the west direction towards the territory of Georgia. Indeed the next Fig. 2 (D) shows that the dust storm coming from the Karakum desert reached the territory of Georgia at 06:00 hours on 27 July 2018. It should be noted that besides the dust cloud observed over Georgia, there was a large dust cloud over the North Caucasus, Russia moving north-west (see Fig. 2 (D)).

Unlike Fig. 2 (D), Fig. 2 (E) presents result of simulations executed on the fine-resolution grid for the same moment of time (06:00 on 27 July 2018). Figure $2(\mathrm{E})$, obtained by calculations on the fineresolution grid, obviously shows that the dust cloud originated in Turkmenistan reached the territory of Abkhazia as opposed to the Fig. 2 (D) which was obtained by calculations on the corse-resolution grid. Figure 2 (F) using the fine-resolution grid at the altitude of $1.5 \mathrm{~km}$ a.s.l. shows that dust cloud reached the Black Sea coastal area at 10:00 on 27 July 2018. From the Fig. $2(\mathrm{G})$ it is evident that the dust cloud is stretching almost above all the territory of Georgia at $1.5 \mathrm{~km}$ a.s.l. and reached the Main Caucasus Mountains at 14:00 on 27 July 2018. Figure $2(\mathrm{H})$ represents the results of calculations executed on the fine-resolution grid at $1.5 \mathrm{~km}$ a.s.1. at 18:00 on 27 July 2018. Figure $2(\mathrm{H})$ obviously shows that the main dust cloud was leaving eastern Georgia crossing the Likhi Mountain Ridge spreading over western Georgia and north-eastern costal area of the Black Sea at 18:00 on 27 July 2018. Figure $2(\mathrm{H})$ also shows that the main dust cloud was not able to cross the Main Caucasus Ridge and the dust observed over Russia were brought from the Caspian Sea by different air masses.



Figure 2. Dust cloud transfer from the Karakum desert towards the territory of Georgia executed on coarse (A-D) and fine mesh resolution grids (E-H). A) at 06:00 on 26 July 2018; B) at $08: 00$ on 26 July 2018 ; C) at $16: 00$ on 26 July 2018 ; D) at $06: 00$ on 27 July 2018 ; E) 06:00 on 27 July 2018 ; B) 10:00 on 27 July 2018; C) 14:00 on 27 July 2018; D) 18:00 on 27 July 2018. 


\section{Conclusions}

In this study, WRF model was used to simulate meteorological conditions resulting in the transportation and accumulation of dust over the Caucasus (Georgia). We studied the intense dust storm events, originating in the Sahara and Sahel in Africa, Arabian and ar-Rub' alKhali deserts located in the Middle East, Kyzylkum, Karakum and the Aralkum in Central Asia and the transportation dust into the territory of the Caucasus (Georgia) from December 2017 to September 2018 by WRF Chem dust v.3.6.1 model. The model was not able to simulate dust transportation from the Taklimakan and Gobi deserts as they are located at a large distance from the Caucasus region and simulations of dust aerosols transportation in the troposphere over a short period of time did not produce satisfactory results. By contrast, the Karakum, Kyzylkum and Aralkum are nearer to the Caucasus and strong eastern atmospheric processes enable dust transport to the Caucasus. Our results showed that: (i) WRF model was able to simulate dust aerosols transportation to the Caucasus well in conditions of a complex topography; (ii) dust aerosols were transported equally from the African, Middle east and west Asian deserts during the study period; (iii) using the fine resulotion grid $(12.4 \mathrm{~km})$ improved the quality of the numerical simulations; and (iv) dust aerosol is an important factor affecting the climate system of Georgia.

Acknowledgement: The research was funded by the Shota Rustaveli National Scientific Foundation Grant N FR17_548. Thanks to Dr. N. Kutaladze and Mr. G. Mikuchadze for their efforts in configuration the nested grid WRF v.3.6 model for the Caucasus region. The computer time for this study was provided by the Georgian Research and Education National Association GE-01-GRENA under the leadership of Dr. R. Kvatadze. Thanks to the review comments from two anonymous reviewers which were very helpful for improving the manuscript.

\section{References}

[1] O. Alizadeh-Choobari, P. Zawar-Reza, A. Sturman, Atmos. Res. 143, 328-341 (2014)

[2] R.J. Charlson, S.E. Schwartz, J.M. Hales, R.D. Cess, J.A. Coakley Jr., J.E. Hansen, D.J. Hofmann, Science 255, 423-430 (1992)

[3] M.O. Andreae, D. Rosenfeld, Earth-Sci. Rev. 89, 13-41 (2008)

[4] S. Twomey, Atmos. Environ. 8, 1251-1256 (1974)

[5] S. Kutuzov, M. Shahgedanova, V. Mikhalenko, P. Ginot, I. Lavrentiev, S. Kemp, The Cryosphere 7, 1481-1498 (2013)

[6] M. Shahgedanova, S. Kutuzov, K. H. White, G. Nosenko, Atmos. Chem. Phys. 13, 1797-1808 (2013)

[7] S.S. Kutuzov, V.N. Mikhalenko, M.V. Shahgedanova, P. Ginot, A.V. Kozachek, T.M.
Kuderina, I.I. Lavrentiev, G.V. Popov, Ice and Snow 54, 5-15 [in Russian] (2014)

[8] V. Mikhalenko, S.Sokratov, S. Kutuzov, P. Ginot, M. Legrand, S. Preunkert, I. Lavrentiev, A. Kozachek, A. Ekaykin, X. Faïn, S. Lim, U. Schotterer, V. Lipenkov, P. Toropov, The Cryosphere 9, 2253-2270 (2015)

[9] S.S. Kutuzov, V. Mikhalenko, A. Grachev, P. Ginot, I. Lavrentiev, A. Kozachek, V. Krupskaya, A. Ekaykin, L. Tielidze, P. Toropov, Environ. Earth Sci. 75, 1488 (2016)

[10]M. Kordzakhia, Climate of Georgia. Tbilisi [in Georgian] (1961)

[11] Sh. Javakhishvili, Georgian Climate Description by the Months. Publishing House "Ganatleba". Tbilisi [in Georgian] (1988)

[12] Sh. Javakhishvili, Atmospheric precipitations on the territory of Georgia. Tbilisi [in Georgian] (1981)

[13] T. Davitashvili, N. Kutaladze, R. Kvatadze, G. Mikuchadze, Scalable Computing: Pract. and Experience 19, 87-96 (2018)

[14] T. Davitashvili, Inter. J. of Energy and Environment 12, 80-86 (2018) 